\title{
Diagnosa Keperawatan
}

\section{salsabnafiah@gmail.com}

\section{Latar Belakang}

Keperawatan merupakan suatu bentuk layanan kesehatan professional yang merupakan bagian integral dari layanan kesehatan berbasis ilmu dan kiat keperawatan, yang berbentuk layanan bio-psiko-sosio-spritual komprehensif yang ditunjukkan bagi individu, keluarga, kelompok, dan masyarakat baik sehat maupun sakit, yang mencakup keseluruhan proses kehidupan manusia (Lokakarya Keperawatan Nasional, 1983). Kontribusi keperawatan dalam meningkatkan derajat kesehatan masyarakat didasarkan pada beberapa konsep keperawatan. Pertama, asuhan yang diberikan perawat bersifat holistic-menyeluruh pada semua aspek "manusia" klien, bukan berfokus pada aspek biologis semata. Kedua, sasaran asuhan keperawatan adalah klien, mulai tingkat individu sampai tingkat masyarakat. Ketiga, lingkup layanan keperawatan bukan terbatas pada klien yang sakit saja, tetapi juga klien yang sehat.

Sebagai seorang perawat professional memerlukan pengantar proses keperawatan dalam melakukan tindakan keperawatan. Untuk mencapai pelayanan keperawatan yang professional diperlukan proses keperawatan yang sistematika. Proses keperawatan tentunya bukan sesuatu hal yang asing bagi Anda, karena setiap hari anda bergelut dengan proses ini pada saat Anda memberikan pelanyanan keperawatan kepada pasien.

Apakah proses keperawatan itu? Proses keperawatan adalah suatu cara atau metode yang sistematis dalam memberikan asuhan keperawatan yang dilakukan oleh perawat dan bekerjasama dengan pasien (induvidu, keluarga, masyarakat) yang bertujuan untuk mengidentifikasi masalah keperawatan dengan melakukan pengkajian, menentukan diagnosa, merencanakan tindakan yang akan dilakukan, melaksanakan tindakan serta mengevaluasi hasil asuhan keperawatan yang telah diberikan dengan berfokus pada pasien, berorientasi pada tujuan yang telah ditetapkan bersama.

Selanjutnya bagaimana tahapan proses keperawatan itu? Menurut Craven dan Hirnle bahwa proses keperawatan memiliki enam fase yaitu: pengkajian, diagnosa, tujuan, rencana tindakan, implementasi, dan evaluasi. Kemudian teori lain menyatakan bahwa proses keperawatan adalah sarana atau alat yang digunakan oleh seorang perawat dalam bekerja dan tata cara pelaksanaannya tidak boleh dipisah-pisah antara tahap pertama, kedua, ketiga dan seterusnya. Tahap pertama pengkajian, tahap kedua menegakkan diagnosa keperawatan, 
tahap ketiga Menyusun rencana keperawatan yang mengarah kepada penanganan diagnosa keperawatan, tahap keempat diimplementasikan dan tahap kelima atau tahap terakhir adalah dievaluasi. Orientasi dari pelayanan asuhan keperawatan adalah pada pencapaian tujuan asuhan keperawatan. Asuhan keperawatan baru dapat dikatakan berhasil dan selesai jika semua tujuan asuhan keperawatan yang telah ditetapkan dalam perencanaan keperawatan telah tercapai.

\section{Metode}

Metode yang digunakan untuk memperoleh informasi dan data yaitu menggunakan metode literasi membaca jurnal, buku, dan karya ilmiah lainnya.

\section{Hasil}

Melalui hasil literasi membaca jurnal, buku, dan karya ilmiah, didapatkan bahwa dalam dalam dokumentasi diagnosa keperawatan memerlukan beberapa cara serta tahap agar data kesehatan dikumpulkan bersifat rinci dan akurat.

\section{Pembahasan}

\section{A. Pengertian Diagnosa Keperawatan}

Diagnosa keperawatan adalah keputusan klinis mengenai seseorang, keluarga, atau masyarakat sebagai akibat dari masalah kesehatan atau proses kehidupan yang aktual atau potensial. Diagnosa keperawatan merupakan dasar dalam penyusunan rencana tindakan asuhan keperawatan.Diagnosis keperawatan sejalan dengan diagnosis medis sebab dalam mengumpulkan data-data saat melakukan pengkajian keperawatan yang dibutuhkan untuk menegakkan diagnosa keperawatan ditinjau dari keadaan penyakit dalam diagnosa medis.

\section{B. Tujuan Dokumentasi Diagnosa Keperawatan}

Tujuan dokumentasi diagnosa keperawatan adalah:

1. Menyampaikan masalah klien dalam istilah yang dapat dimengerti semua perawat

2. Mengenali masalah-masalah utama klien pada pengkajian

3. Mengetahui perkembangan keperawatan

4. Masalah dimana adanya respons klien terhadap status kesehatan atau penyakit

5. Faktor-faktor yang menunjang atau menyebabkan suatu masalah (etiologi)

6. Kemampuan klien untuk mencegah atau menyelesaikan masalah

\section{Metode Dokumentasi Diagnosa Keperawatan}

Metode dokumentasi diagnosa keperawatan meliputi: 
1. Tuliskan masalah/problem pasien atau perubahan status kesehatan pasien

2. Masalah yang dialami pasien didahului adanya penyebab dan keduanya dihubungkan dengan kata "sehubungan dengan atau berhubungan dengan"

3. Setelah masalah (problem) dan penyebab (etiologi), kemudian diikuti dengan tanda dan gejala (symptom) yang dihubungkan dengan kata "ditandai dengan"

4. Tulis istilah atau kata-kata yang umum digunakan

5. Gunakan bahasa yang tidak memvonis

\section{Langkah-Langkah Penulisan Diagnosa Keperawatan}

Langkah-langkah dalam penulisan diagnosa keperawatan terdiri dari:

1. Pengelompokan Data dan Analisa data

a. Data Subjektif

Contoh:

"Pasienmengeluhkan nyeri saat menelan karena ada tumor di leher, akibatnya BB

turun lebih dari $10 \mathrm{~kg}$ dalam 12 bulan berakhir, karena nyeri menelan."

b. Data Objektif

Contoh:

$\mathrm{TB}=165 \mathrm{~cm}, \mathrm{BB}=45 \mathrm{~kg}$

2. Interpretasi Data

Contoh:

Gangguan pemenuhan nutrisi kurang dari kebutuhan tubuh.

3. Validasi Data Validasi data ini dilakukan untuk memastikan ke akuratan diagnosa dimana perawat bersama pasien memvalidasi diagnosa sehingga diketahui bahwa pasien setuju dengan masalah yang sudah dibuat dan faktor-faktor yang mendukungnya. Contoh:

Perawat mengukur BB pasien akibat tumor yang dideritanya.

4. Penyusunan Diagnosa Keperawatan (dengan rumusan $\mathrm{P}+\mathrm{E}+\mathrm{S}$ )

$\mathrm{P}=$ Problem

$\mathrm{E}=$ Etiolog

$\mathrm{S}=$ Symptom .

Contoh:

Gangguan pemenuhan nutrisi: kurang dari kebutuhan tubuh berhubungan dengan intake yang tidak adekuat ditandai dengan klien mengatakan BB turun lebih dari $10 \mathrm{~kg}$ dalam 12 bulan terakhir, $\mathrm{TB}=165 \mathrm{~cm}, \mathrm{BB}=45 \mathrm{~kg}$.

Dari contoh diagnosa di atas, dapat diketahui:

Problemnya adalah: gangguan pemenuhan nutrisi kurang dari kebutuhan tubuh. 
Etiologinya adalah: intake yang tidak adekuat.

Symptomnya adalah: klien mengatakan BB turun lebih dari $10 \mathrm{~kg}$ dalam 12 bulan terakhir, klien mengeluh nyeri saat menelan, sehinggan menghindari untuk tidak makan, $\mathrm{TB}=170 \mathrm{~cm}$, $\mathrm{BB}=50 \mathrm{~kg}$.

\section{E. Kategori Diagnosa Keperawatan}

Diagnosa keperawatan dapat dibedakan menjadi 5 kategori: (1) Aktual, (2) Resiko, (3) Kemungkinan, (4) Keperawatan welness, (5) Keperawatan Sindrom.

1. Aktual

Diagnosa Keperawatan aktual menjelaskan masalah nyata saat ini sesuai dengan data klinik yang ditemukan.Syarat menegakkan diagnosa keperawatan aktual harus ada unsur PES.Symptom (S) harus memenuhi kriteria mayor dan sebagian kriteria minor dari pedoman diagnosa NANDA. Misalnya: Hasil pengkajian diperoleh data klien mual, muntah, diare dan turgor jelek selama 3 hari. Diagnosa: Kekurangan volume cairan tubuh berhubungan dengan kehilangan cairan secara abnormal.

\section{Risiko}

Diagnosa Keperawatan Risiko menjelaskan masalah kesehatan yang nyata akan terjadi jika tidak dilakukan intervensi. Syarat menegakkan risiko diagnosa keperawatan adanya unsur PE (problem dan etiologi).Penggunaan istilah "risiko dan risiko tinggi" tergantung dari tingkat keparahan/kerentanan terhadap masalah. Diagnosa: "Risiko gangguan integritas kulit berhubungan dengan diare yang terus menerus".

\section{Kemungkinan}

Diagnosa Keperawatan Kemungkinan menjelaskan bahwa perlu adanya data tambahan untuk memastikan masalah keperawatan kemungkinan.Pada keadaan ini masalah dan faktor pendukung belum ada tapi sudah ada faktor yang dapat menimbulkan masalah.Syarat menegakkan kemungkinan diagnosa keperawatan adanya unsur respons (Problem) dan faktor yang mungkin dapat menimbulkan masalah tetapi belum ada.

Contoh:

Diagnosa: Kemungkinan gangguan konsep diri: rendah diri/terisolasi berhubungan dengan diare. Perawat dituntut untuk berfikir lebih kritis dan mengumpulkan data tambahan yang berhubungan dengan konsep diri.

\section{Diagnosa Keperawatan "Wellness"}

Diagnosa keperawatan wellness (sejahtera) adalah keputusan klinik tentang keadaan individu, keluarga, dan atau masyarakat dalam transisi dari tingkat sejahtera tertentu ke tingkat sejahtera yang lebih tinggi. Ada 2 kunci yang harus ada: 
1) Sesuatu yang menyenangkan pada tingkat kesejahteraan yang lebih tinggi

2) Adanya status dan fungsi yang efektif.

\section{Daftar Pustaka}

Budiono \& Sumirah. (2016). Konsep Dasar Keperawatan. Jakarta: Bumi Medika

Budiono. (2016). Konsep Dasar Keperawatan. Jakarta: Pubsdik SDM Kesehatan.

Dermawan, D. (2012). Proses Keperawatan Penerapan Konsep \& Karangka Kerja Yogyakarta: Gosyen

Erlin Ifadah. 2012. Penerapan Dokumentasi Keperawatan Elektronik Dalam Praktek

Keperawatan, Jakarta, FIK UI.

Herdman, T. H. (2018). NANDA-1 Diagnosis Keperawatan Definisi dan Klasifikasi 20182020. Jakarta: EGC.

Olfah Yustiana. (2016). Dokumentasi Keperawatan. Jakarta : : Pubsdik SDM Kesehatan.

Rachman, N. (2016). Applied Nanda, NIC, NOC, Pada Praktek Klinik Keperawatan Kebutuhan Dasar Manusia. Yogyakarta: Trans Medika

Rutami. (2012, Oktober). Pelaksanaan Proses Pengkajian Keperawatan di Ruang Rawat Inap RSUP H. Adam Malik Medan. Jurnal Keperawatan, 1(2).

Rosdahl, C. B., \& Kawalski, M. T. (2017). Buku Ajar Keperawatan Dasar. Jakarta: EGC.

Tarwoto, \& Wartono. (2015). Kebutuhan Dasar Manusia dan Proses Keperawatan. Yogyakarta: Salemba Medika.

Simamora. R. H. (2008) The correlation of ward chief's giving direction and command and the performance of on-duty nurses at Jember dr. Subandi general hospital inpatient wards. jurnal Administrasi dan Kebijakan Kesehatan, (https://fkm.unair.ac.id/jurnal-administr)

Simamora, R. H. (2019). Development of Guidelines for Applying appropriate Patient Identification to Achieve Patient Safety Goal

INC2019 12th International Nursing Conference. 2019.10455 - 455 (1 pages) UCI(KEPA) : I410-ECN-01012019-512-001224337 
